\title{
Simple Remedy of Palpitations in Pregnancy from Iranian Traditional Medicine: A Mini Review
}

\author{
Roshanak Mokaberinejad ${ }^{1}$ and Shahrbanoo Abdolhosseini ${ }^{2 *}$ \\ ${ }^{1}$ Department of Traditional Medicine, Shahid Beheshti University of Medical Sciences, Iran \\ ${ }^{2}$ Minimally Invasive Surgery Research Center, Iran University of Medical Sciences, Iran
}

Submission: November 07, 2017; Published: December 18, 2017

*Corresponding author: Shahrbanoo Abdolhosseini, Department of Traditional Medicine Minimally Invasive Surgery Research Center, Iran University of Medical Sciences, Tehran, Iran, Email: shabdolhosseini@razi.tums.ac.ir

Keywords: Palpitations; Pregnancy; Traditional medicine; Integrative medicine

\section{Mini Review}

Palpitations are one of the common problems in pregnant women. In pregnancy, heart rate (HR) increases by $25 \%$; thus sinus tachycardia, especially in the third trimester, is common. Prevalence of Ectopic beats and non-sustained arrhythmia is more than $50 \%$ of pregnant women investigated for palpitations while sustained tachycardia are less common about 2-3/1000 [1]. Treatment of arrhythmias in pregnant women is similar to that in non-pregnant but a special attention must be given to prevent adverse fetal effects [2].

Nowadays there is also a great interest especially by women in their reproductive age for alternative medicine which requires adequate knowledge from both healthcare providers and users [3]. One of the oldest and most influential complementary therapies in the world is Persian medicine. Iranian Traditional Medicine (ITM) or Persian Medicine consists of the entirety of all the information and practices used in prevention, diagnosis of diseases in Persia from ancient periods to present. Iranian Traditional Medicine roots back to over 8000 year B.C. and it is a division if not the sources of the so called Arabic-Unani medicine as quoted by Cyril Elgood, the English medical historian [4].

Iranian Traditional Medicine (ITM) or Persian Medicine, a several thousand years old medical practice, carried out valuable experiences in the field of maternal health, which have been recorded in manuscripts of prominent Iranian scientists and are being protected in world's renowned libraries [5]. From Iranian traditional medicine point of view, there are some options to manage palpitation with little risk to mother or fetus.

Avicenna (980-1037A.D) and some other famous Iranian traditional physicians have described palpitation in their manuscripts. Various natural remedies have been used in Iranian traditional medicine for palpitation of pregnancy. These remedies have been used for many years by Iranian physicians such as Avicenna for the treatment of palpitation in pregnancy. If there is no cardiac cause for palpitation, Simple treatments to improve palpitation of pregnancy in traditional medicine references include:

A. Lifestyle modification with Moderate exercise such as non-long walking may help [6].

B. Recommended foods are light and easily digested such as chicken meat, Quebec or wings of birds that is cooked with unripe grapes and pomegranates.

C. Vegetables such as Cucumbers (Cucumissativus), Cucurbitapepo, spinach (Spinaciaoleracea), chicory (Cichoriumintybus L), Common Purslane (Portulacaoleracea) [7].

D. Dram hot water $[6,8]$.

E. Dram hot water and rose water, especially if a teaspoonful of Echium leaves or a piece of stick cinnamon (Cinnamomumverum) is brewed, quickly resolves palpitation due to stomach disease [9].

They considered the association between heart and stomach in a number of disease and believed that the cardiovascular manifestations appearing in gastric diseases include chest pain, palpitation, and syncope. In modern study, an etiologic relationship between cardiac and gastric diseases has also been observed. The association between atrial fibrillation (AF) and GERD has been well documented in some studies [10]. 
According to Iranian traditional medicine viewpoints regarding the issue of palpitations in pregnancy and the simple remedies prescribed to control it, by researching and studying in this field of study, approaches might be revealed to treat this disorders.

\section{References}

1. Adamson DL, Nelson-Piercy C (2007) Managing palpitations and arrhythmias during pregnancy. Heart 93(12): 1630-1636.

2. Gowda RM, Khan IA, Mehta NJ, Vasavada BC, Sacchi TJ, et al. (2003) Cardiac arrhythmias in pregnancy: clinical and therapeutic considerations. Int J Cardiol 88(2): 129-133.

3. Barnes PM, Bloom B, Nahin RL (2008) Complementary and alternative medicine use among adults and children: United States, 2007. Natl Health Stat Report 10(12): 1-23.

4. Rezaeizadeh H, Alizadeh M, Naseri M, Ardakani MS (2009) The traditional Iranian medicine point of view on health and disease. Iranian J Publ Health 38(1): 169-172.
5. Jafari-Dehkordi E, Mokaberinejad R, Minaei B, Sohrabvand F, Nazem E et al. (2013) A Review of pioneer physicians' work on maternal health in pregnancy in ancient Iran; Narrative systematic review. Iran J Public Health 42(12): 1340-1346.

6. Ibn Sina AAH (2005) Medicine. In: Al-Din IS, Al-Qanon Fal-Tibb (Eds.) Alamy Le- Al-Matbooat Institute, Lebanon, p. 455.

7. Baladi A Tadbir, Al-hobali va Al-sebyan (1980) Dar Al-Rashid pub, Baghdad, Iraq, p. 155.

8. Rhazes M, Al-hāwi fi al-Tibb (2002) Dār Al-Ehyā’' Al-Torās Al-Arabi, Beirut, Lebanon, p. 442.

9. Khorasani M, Al-hikmah K (2006) Esmailian publications, Qom, Iran 2: 147.

10. Shirzad M, Mosaddegh M, Minaii B, Nasrabadi NA, Ahmadian-Attar MM, et al. (2013) The relationship between heart and stomach in Iranian traditional medicine: a new concept in cardiovascular disease management. Int J Cardiol 165(3): 556-557.

\section{Your next submission with Juniper Publishers} will reach you the below assets

- Quality Editorial service

- Swift Peer Review

- Reprints availability

- E-prints Service

- Manuscript Podcast for convenient understanding

- Global attainment for your research

- Manuscript accessibility in different formats

( Pdf, E-pub, Full Text, Audio)

- Unceasing customer service

Track the below URL for one-step submission https://juniperpublishers.com/online-submission.php 